\title{
RANCANG BANGUN SISTEM INFORMASI BATAM DIRECTORY MENGGUNAKAN METODE BACKWARD CHAINING BERBASIS MOBILE
}

\author{
Oleh : \\ Hamsir $^{1}$, Gunadi W Nurcahyo ${ }^{2}$, Sarjon Defit ${ }^{3}$ \\ ${ }^{1}$ Sekolah Tinggi Teknik (STT) Ibnu Sina Batam \\ ${ }^{2,3}$ UPI - YPTK Padang \\ Email: hamsirsuksesselalu@gmail.com ${ }^{1)}$
}

\begin{abstract}
This article is designed for an information system in the form of expert system applications to present information on Batam Directory. The purpose of this system is to help provide information about the city of Batam as a whole to the residents of Batam city in particular and thelocal and foreign tourists as well as prospective investors in general. The system presents information in the form of public service to the residents of Batam city government and other newcomers as well as products and services are made and offered by the business and government. The analysis was done by determining the first goal, then do these arching to obtain the desired information. The design system uses backward chaining inference method to the implementation ofthe system using My-SQL database systems and programming languages of PHP and JQuery. The system is based on mobile, so it can be accessed using a mobile device.
\end{abstract}

Keywords: BackwardChaining, Expert Systems, BatamDirectory, My-SQL, PHP, JQuery

\section{PENDAHULUAN}

Inference engine merupakan modul yang berisi program tentang bagaimana mengendalikan proses reasoning. Ada dua metode inferensi yang penting dalam sistem pakar, yaitu runut maju (forward chaining) dan runut balik (backward chaining).Dalam tulisan ini, inference engine yang digunakan adalah Backward Chaining. Cukup banyak peneliti penggunakan backward chaining dalam penelitiannya, diantaranya adalah Saylani, 2012atau Homeier dan Thach, 2012.

Penulis melakukan penelitian Kota Batam dengan jumlah penduduk berdasarkan sensus penduduk tahun
2012 sebesar 1.146.231 jiwa. Jumlah wisatawan mancanegara selama bulan Januari hingga Mei 2012 sebanyak 477.275 jiwa meningkat sebesar 8,4 persen dibandingkan periode yang sama tahun 2011 yang tercatat 440.280 jiwa.

Permasalahan yang dihadapi penduduk kota Batam maupun wisatawan adalah sulitnya mendapatkan informasi tentang kota Batam secara keseluruhan.

Beberapa informasi telah disajikan oleh pemda kota batam, namun belum memenuhi kebutuhan masyarakat kota Batam khususnya yang memiliki mobilitas tinggi, apalagi informasinya sulit diakses. Untuk itu dibutuhkan sebuah sistem informasi berupa Batam Directory yang berisi seluruh informasi 
tentang Kota Batam yang dapat diakses dengan mudah, kapan dan dimana saja.

Sistem Pakar dapat menyelesaikan permasalahan diatas dengan menerapkan Metode Backward Chaining pada rancang bangun Sistem Informasi Batam Directory berbasis mobile.Bahasa Pemrograman yang sesuai dalam rancang bangun diatas pada sisi client adalah Java Query Mobile(JQuery Mobile) dan pada sisi Admin adalah PHP dengan dukungan teknologi database $M y-S Q L$ yang cukup handal mengelola database yang besar.

\section{Perumusan Masalah}

Berdasarkan latar belakang masalah maka rumusan masalah adalah sbb:

1. Bagaimana menerapkan metode Backward Chaining pada pembangunan sistem informasi Batam Directory berbasis mobile?

2. Bagaimana Metode Backward Chaining dapat digunakan untuk merancang sebuah sistem informasi Batam Directory berbasis mobile yang efektif dan efisien pada Pemerintah Kota Batam ?

\section{LANDASAN TEORI}

\section{Pengertian Sistem Pakar}

Secara umum, sistem pakar (expert system) adalah sistem yang berusaha mengadopsi pengetahuan manusia ke komputer.Sistem pakar yang baik dirancang agar dapat menyelesaikan suatu permasalahan tertentu dengan meniru kerja dari para ahli. Ada beberapa definisi tentang sistem pakar, antara lain:

Menurut Durkin : Sistem pakar adalah suatu program komputer yang dirancang untuk memodelkan kemampuan penyelesaian masalah yang dilakukan oleh seorang pakar.
1. Menurut Ignizio : Sistem pakar adalah suatu model dan prosedur yang berkaitan, dalam suatu domain tertentu, yang mana tingkat keahliannya dapat dibandingkan dengan keahlian seorang pakar.

2. Menurut Giarratano dan Riley : Sistem pakar adalah suatu sistem komputer yang bisa menyamai atau meniru kemampuan seorang pakar (Sri Kusumadewi, 2003).

\section{Konsep Dasar Sistem Pakar}

Konsep dasar dari suatu sistem pakar mengandung beberapa unsur atau elemen, yaitu keahlian, ahli, pengalihan keahlian, inferensi, aturan, dan kemampuan menjelaskan. Salah satu fitur yang harus dimiliki oleh sistem pakar adalah kemampuan untuk menalar (reasoning).

\section{Struktur Sistem Pakar}

Sistem pakar disusun oleh dua bagian utama, yaitu lingkungan pengembangan (development environment) dan lingkungan konsultasi (consultation environment), seperti pada gambar 1.

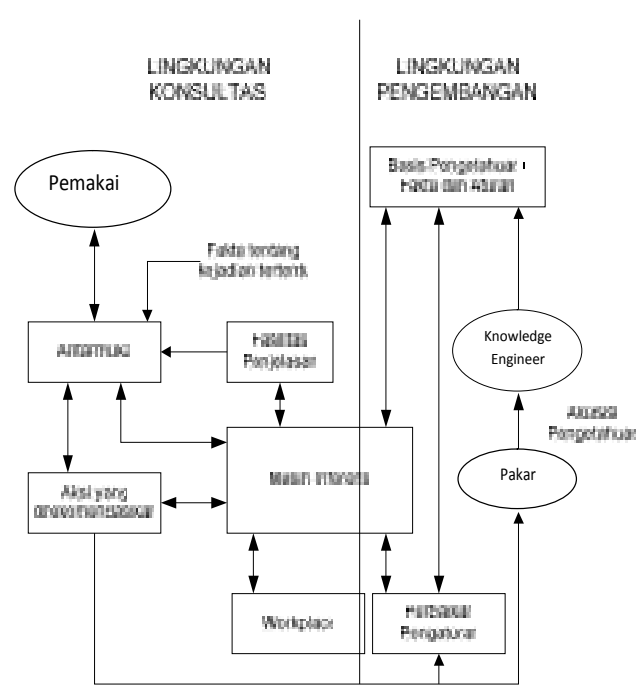

Gambar 1 Struktur Sistem Pakar 
Keteralgan gambar:

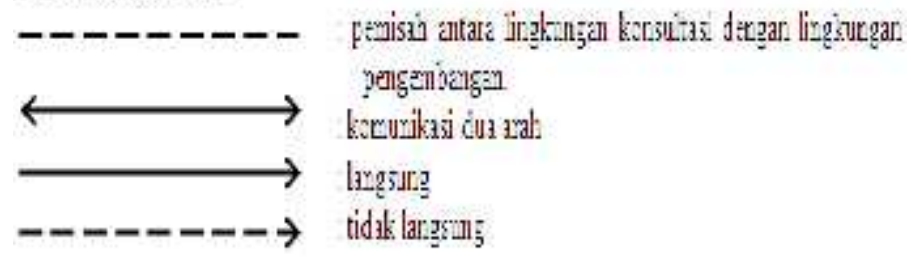

\section{Akuisisi Pengetahuan}

Menurut Turban (1998:1), terdapat empat metode utama dalam akusisi pengetahuan yaitu :

a. Wawancara

Wawancara adalah metode akusisi yang paling banyak digunakan. Dalam metode ini melibatkan pembicaraan dengan pakar secara langsung dalam suatu wawancara.

b. Analisis Protokol

Dalam metode akusisi ini, pakardiminta untuk melakukan suatu pekerjaandan mengungkapkan proses pemikirandengan menggunakan katakata.

c. Observasi Pada Pekerjaan Pakar

Dalam metode ini, pekerjaan dalambidang tertentu yang dilakukan pakardirekam dan diobservasi.

d. Induksi Aturan Dari Contoh

Metode ini dibatasi untuk sistemberbasis aturan. Induksi adalah suatu prosespenalaran dari kasus ke umum. Suatu sisteminduksi aturan diberi contoh-

diberikan beberapa contoh, sisteminduksi aturan tersebut dapat membuataturan yang benar untuk kasus-kasus contoh.

\section{Bingkai (Frame)}

Bingkai berupa ruang-ruang (slots)
yang berisi atribut untuk
mendeskripsikan pengetahuan.
Pengetahuan yang termuat dalam slot
dapat berupa kejadian, lokasi, situasi,
ataupun elemen-elemen lainnya. Bingkai
digunakan untuk merepresentasikan
pengetahuan deklaratif. Berikut adalah
contoh tabel model representasi
pengetahuan bingkai (frame).

contoh darisuatu masalah yang hasilnya telah diketahui. Setelah

\section{Mengembangkan Sistem Pakar}

Seperti layaknya pengembangan perangkat lunak, pada pengembangan sistem pakar inipun diperlukan beberapa tahapan seperti terlihat pada gambar berikut ini [Sri Kusumadewi, 2003].

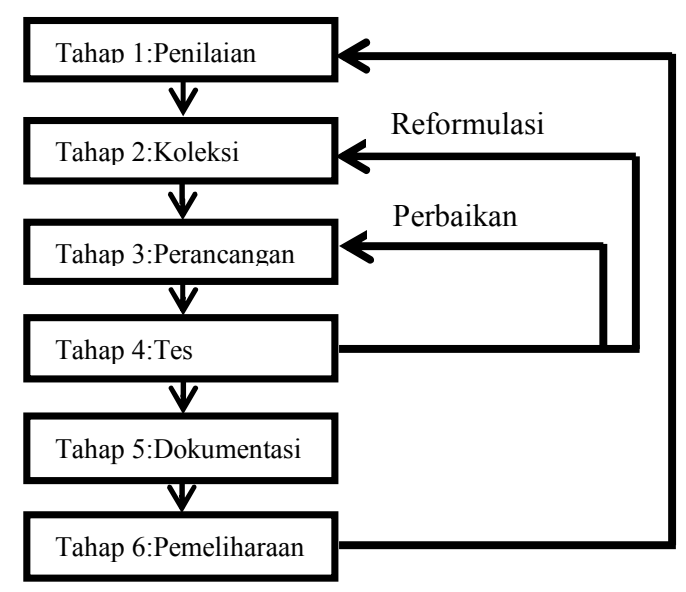

Gambar 2 Tahap - tahap
Pengembangan Sistem Pakar

Tabel 1 Representasi Bingkai Pada

Bingkai Penyakit

\begin{tabular}{|l|l|}
\hline \multicolumn{1}{|c|}{ Ruang (Slots) } & \multicolumn{1}{|c|}{ Isi (Fillers) } \\
\hline Nama & \multicolumn{1}{c|}{ Flu } \\
\hline Gejala & a. Bersin \\
& b. Pusing \\
& c. Demam \\
\hline Obat & a. Ultraflu \\
& b. Mixagrib \\
\hline
\end{tabular}




\section{Kaidah Produksi (Production Rule)}

Kaidah menyediakan cara formal untuk merepresentasikan rekomendasi, arahan, atau strategi. Kaidah produksi dituliskan dalam bentuk jika-maka (if-then). Kaidah if-then menghubungkan antaseden (antacedent) dengan konskuensi yang diakibatkannya.

Berbagai struktur kaidah if-then yang menghubungkan obyek atau atribut adalah sebagai berikut :

JIKA premis MAKA konklusi

JIKA masukan MAKA keluaran

JIKA kondisi MAKA tindakan

JIKA anteseden MAKA

konsekuen

JIKA data MAKA hasil

JIKA tindakan MAKA tujuan

\section{Mekanisme Inferensi}

Ada dua metode inferensi yang paling penting dalam sistem pakar, yaitu runut maju (forward chaining) dan runut balik (backward chaining).

\section{Runut Maju (Forward Chaining)}

Suatu perkalian inferensi yang menggabungkan suatu permasalahan Menurut Giarattano dan Riley dalam runut balik, penalaran dimulai dengan tujuan merunut balik ke jalur yang akan mengarahkan ke tujuan tersebut.

Dalam pendekatan ini pelacakan dimulai dari tujuan, selanjutnya dicari aturan yang memiliki tujuan tersebut untuk kesimpulannya. Selanjutnya proses pelacakan menggunakan premis untuk aturan tersebut sebagai tujuan baru dan mencari aturan lain dengan tujuan baru sebagai kesimpulannya. Proses berlanjut sampai semua kemungkinan ditemukan. Gambar 4 menunjukkan proses backward chaining (Meliana Anandari, 2012). dengan solusinya disebut dengan rantai (chain). Suatu rantai yang dicari atau dilewati atau dilintasi dari suatu permasalahan untuk memperoleh solusinya disebut dengan forward chaining. Cara lain menggambarkan forward chaining ini adalah dengan penalaran dari fakta menuju konklusi yang terdapat dari fakta. Menurut Wilson dalam metode ini, data digunakan untuk menentukan aturan mana yang akan dijalankan, kemudian aturan tersebut dijalankan. Mungkin proses menambahkan data ke memori kerja. Proses diulang sampai ditemukan suatu hasil.

Menurut Giarattano dan Riley, metode inferensi runut maju cocok digunakan untuk menangani masalah pengendalian (controling) dan peramalan (prognosis).

Gambar 3 berikut menunjukkan proses forward chaining.

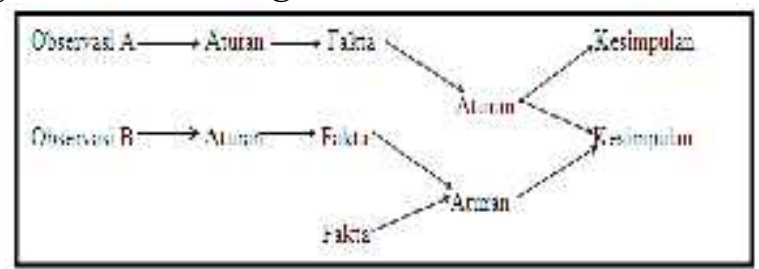

Gambar 3 Proses Forward Chaining

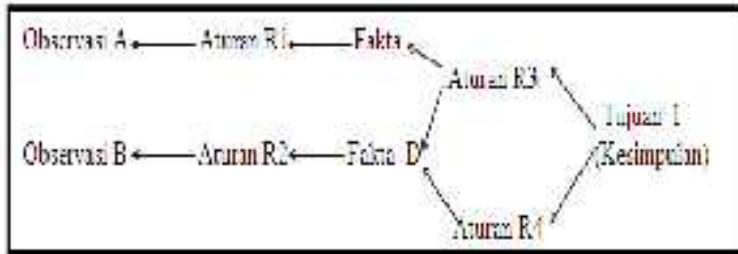

Gambar 4 Proses Backward Chaining

Kedua metode inferensi tersebut dipengaruhi oleh tiga macam penelusuran, yaitu Depth-first search, Breadth-first search, dan best-first search (Hersatoto Lestiyono, 2008).

a. Depth-first search, melakukan penelusuran kaidah secara mendalam dari simpul akar bergerak menurun ketingkat dalam yang berurutan. 


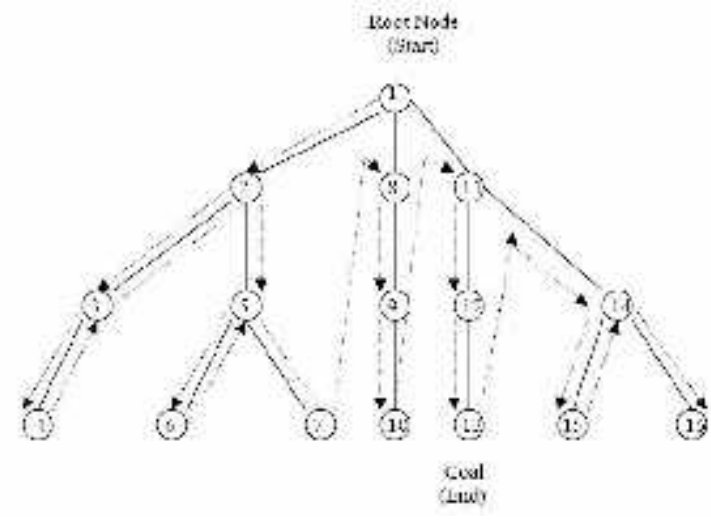

Gambar 5 Diagram Teknik Penelusuran Dept-First Search

b. Breadth-first search, bergerak dari simpulakar, simpul yang ada pada setiap tingkatdiuji sebelum pindah ketingkat selanjutnya.

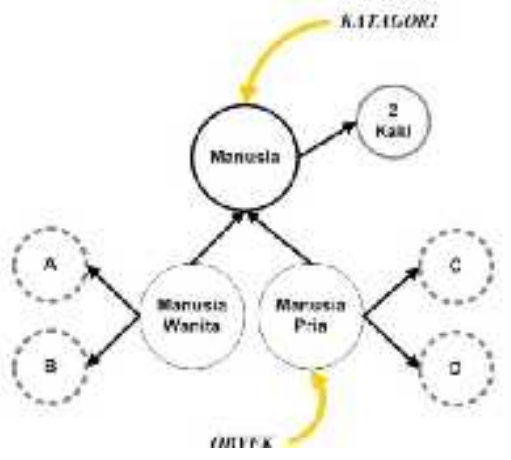

Gambar 6 Diagram Teknik Penelusuran Breadth First Search

c. Best-first search, bekerja berdasarkankombinasi kedua metode sebelumnya.

\section{Penerapan Sistem Pakar dan Backward Chaining}

Salah satu cabang Artificial Intellegent (AI) yang cukup pesat perkembangannya adalah Sistem Pakar (Expert System), terlihat dari makin banyaknya peneliti yang melakukan penelitian menggunakan sistem pakar dari berbagai bidang. Salah satu sistem pakar yang dikembangkan dalam bidang kesehatan yang telah banyak digunakan adalah E2gLite.

\section{ANALISA DAN PERANCANGAN}

Tahap Analisis Sistem Pakar

Dalam pembangunan Sistem Pakar mengidentifikasi Batam Directory diperlukan tahapan - tahapan analisis sebagai berikut :

1. Sistem yang akan dibangun merupakan sistem pakar mengidentifikasi Batam Directory.

2. Mengumpulkan data - data melalui studi literatur, observasi dan wawancara ke masyarakat digunakan sebagai knowledge base.

3. Mempresentasikan pengetahuan yang telah didapat ke dalam tabel pertanyaan

4. Menentukan metode inferensi

5. Menentukan target user

6. Usulan sistem yang akan dibangun.

\section{Analisa Masalah}

Beberapa pendekatan untuk menyelesaikan permasalahan tersebut sebagai berikut :

a. Mempelajari dan melakukan studi kasus mengenai kebutuhan informasi tentang Batam Directory yang sering terjadi.

b. Memahami sistem kerja Batam Directory

c. Membangun sistem informasi berupa sistem pakar yang menyediakan referensi mengenai tata cara pengolahan data Batam Directory.

d. Membangun sistem pakar yang dapat mendeteksi permasalahan pada Batam Directorydan solusinya

e. Pengembangan sistem pakar yang dapat membantu memberikan keputusan secara tepat dan akurat.

\section{Analisa Sistem}

Dari analisis sistem diperoleh beberapa kesimpulan sebagai berikut :

a. Pengembangan sistem pakar harus menyediakan referensi tentang bagaimana tata $\quad-\quad$ cara 
perawatan,pemeliharaan dan petunjuk pengelolaanBatam Directory

b. Diperlukan pengembangan sistem pakar untuk dapat membantu masyarakat dalam mencari informasi yang disajian dalam Batam Directory

c. Proses pengambilan kesimpulan sistem pakar memberikan beberapa pertanyaan berbagai permasalahan yang dihadapi, kemudian pengguna sistem memberikan jawaban dari pertanyaan tersebut.

d. Setelah mengetahui informasiyang dibutuhkan, maka sistem pakar akan memberikan solusi informasi yang dibutuhkan tersebut.

\section{Desain Arsitektur Sistem}

Arsitektur sistem di disain seperti pada Gambar 7.

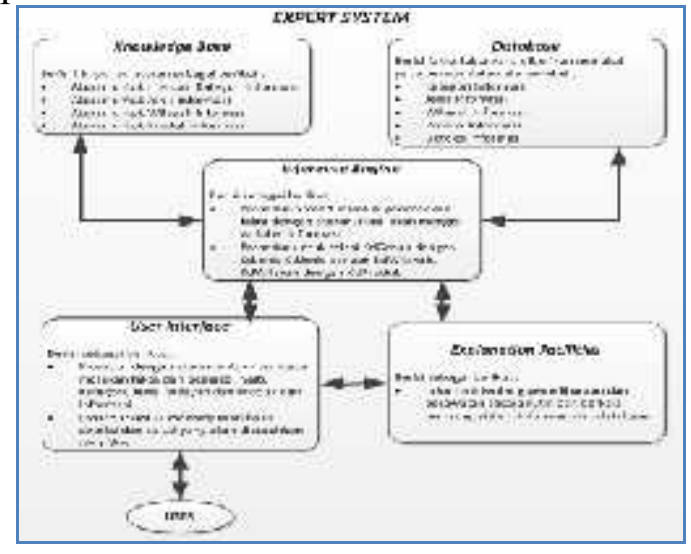

\section{Knowledga Base}

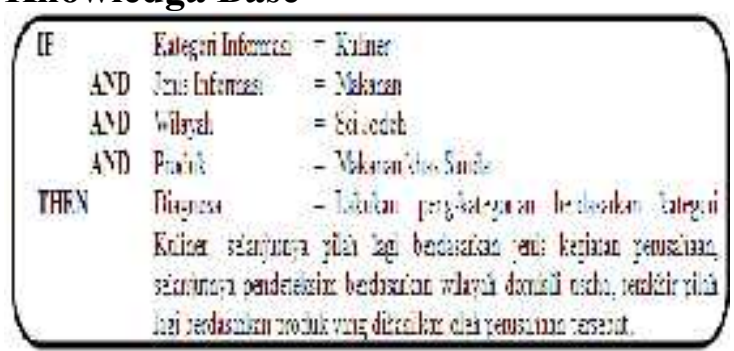

\section{Gambar 10 Rule Ke-3 Katagori Kuliner}

Gambar 7 Desain arsitektur Deteksi Informasi Batam Director
Knowledge Base berisi himpunan aturan atau rule untuk mencari aturan, mencari macam - macam informasi, jenis - jenis informasi. Contoh aturan - aturan adalah sebagai berikut :

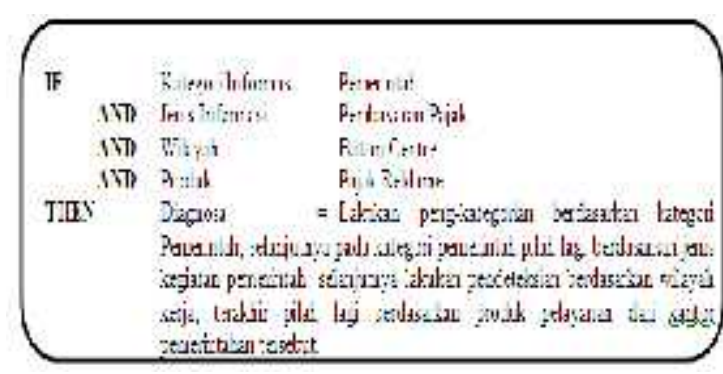

\section{Gambar 8 Rule Ke-1 Katagori Pemerintah}

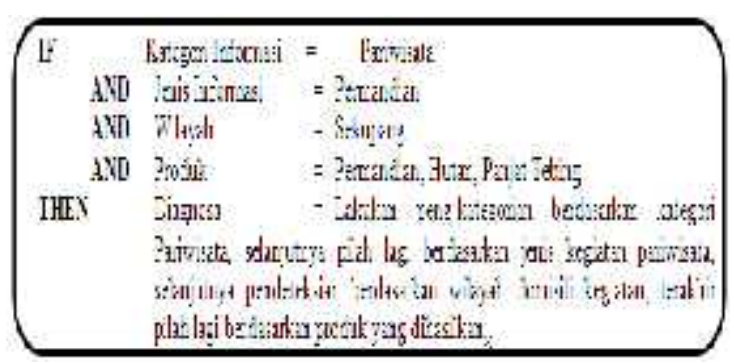

\section{Gambar 9 Rule Ke-2 Katagori Pariwisata}

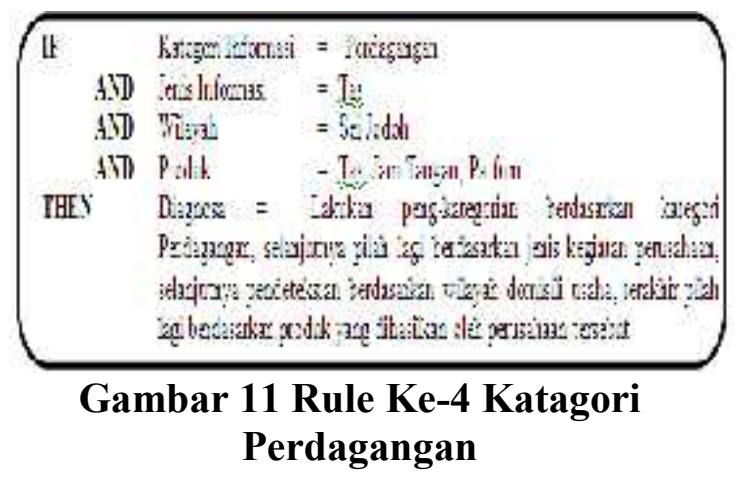




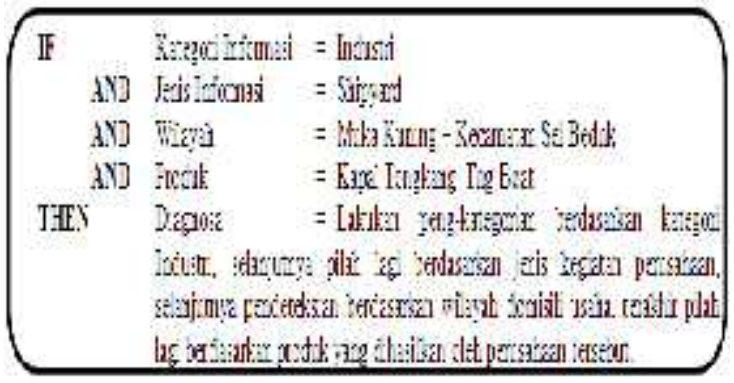

Gambar 12 Rule Ke-5 Katagori

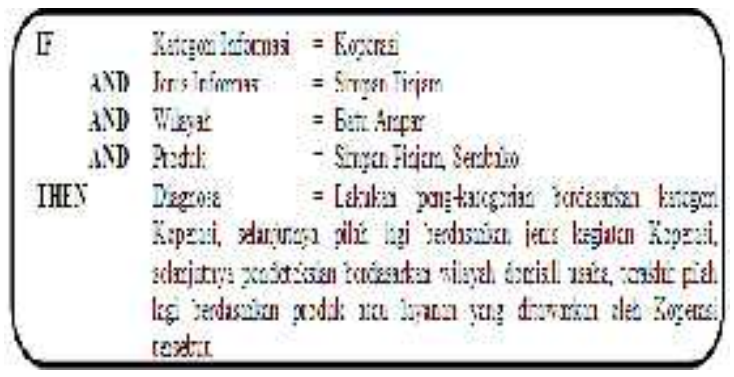

\section{Gambar 13 Rule Ke-6 Katagori} Koperasi

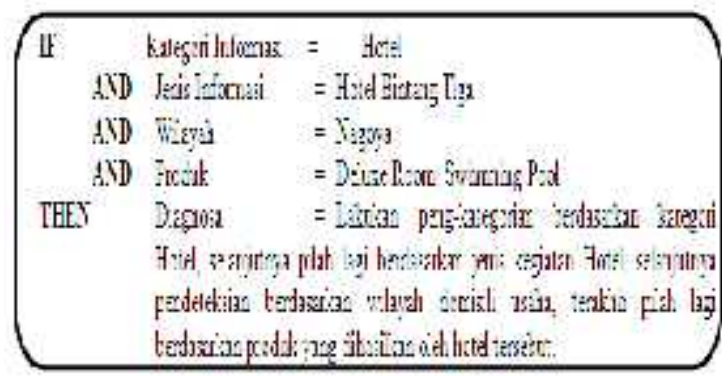

Gambar 14 Rule Ke-7 Katagori Hotel

\section{Database}

Dalam hal ini nama database yang dirancang adalah dbBATAMDIR.SQL.

Database berisi tentang fakta - fakta yang dibutuhkan pemakai, yaitu berupa data - data variabel dari : tabel password, tabel kategori informasi, tabel jenis informasi, tabel wilayah kerja, tabel produk layanan dan tabel diagnosa informasi.

\section{Inference Engine}

Untuk penyelesaian masalah dalam mendeteksi informasi yang dibutuhkan, dalam hal ini menggunakan metode inferensi backward chaining karena dalam mengecek informasi Batam Directory akan dimulai dengan bermacam - macam informasi yang akan ditelusuri, kemudian dilanjutkan dengan jenis - jenis dari bermacam informasi yang dipilih, dan seterusnya sampai pada diagnose informasi dan hasil akhir kesimpulan informasi tersebut.

Sistem pakar yang diaplikasikan pada penelitian ini merupakan sistem pakar yang pada tingkat tertentu dapat bertindak sebagai pendiagnosa informasi dan memberikan rekomendasi informasi terpilih atas goal tersebut. Sistem pakar ini memiliki kemampuan sebagai berikut

1. Menanyakan informasi yang diinginkan

2. Memberikan langkah - langkah yang harus dilakukan mengidentifikasi informasi

3. Menyimpulkan informasi batam directory yang dimaksud

Kerja Sistem Pakar (Searching) dapat digambarkan sebagai berikut:

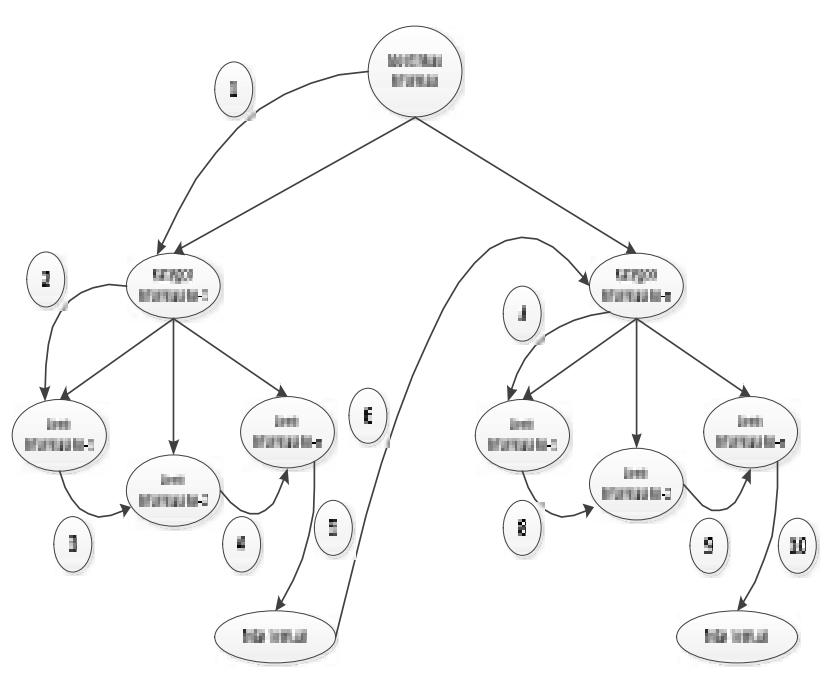

Gambar 15 Kerja Sistem Pakar 


\section{Teknik Inference Engine}

Kinerja sistem dalam pencapaian kesimpulan didasarkan pada langkah langkah berikut :

1. Memulai penalaran dari sekumpulan hipotesa

2. Menemukan ciri - ciri yang sesuai hipotesamenuju fakta - fakta yang mendukung hipotesa tersebut

3. Begitu selanjutnya sampai pada kesimpulan atau goal tercapai.

Proses implementasi sistem inferensi yang menggunakan Backward Chaining dapat diuraikan pada tabel berikut ini

Tabel 2Database Yang Mengandung
Fakta - Fakta
\begin{tabular}{|c|l|}
\hline VARIABEL & \multicolumn{1}{|c|}{ FAKTA - FAKTA } \\
\hline A & Kategori telah tersedia \\
\hline B & Jenis Usaha telah ada \\
\hline C & $\begin{array}{l}\text { Penulisan kata kunci (key } \\
\text { word) }\end{array}$ \\
\hline D & $\begin{array}{l}\text { Informasi Produk telah } \\
\text { tersedia }\end{array}$ \\
\hline E & $\begin{array}{l}\text { Wilayah domisili usaha } \\
\text { diketahui }\end{array}$ \\
\hline Z & Data dapat ditampilkan \\
\hline
\end{tabular}

\section{User Interface}

Pada rancangan menu utama terdiri dari kategori informasi yang tersedia memungkinkan user memilih informasi yang diinginkan dengan tepat, sedangkan rancangan pencarian informasi digunakan untuk memasukkan goal yang diinginkan.

Berdasarkan variable - variable yang telah dikelompokkan, maka dapat diterapkan ke dalam aturan - aturan (knowledge base) yang di tampilkan pada tabel berikut ini :

Tabel 3 Database (Fakta - Fakta) Setelah Eksekusi

\begin{tabular}{|c|c|}
\hline NOMOR & ATURAN \\
\hline R-1 & IF D THEN E \\
\hline
\end{tabular}

\begin{tabular}{|l|l|}
\hline R-2 & IF E AND B THEN A \\
\hline R-3 & IF A AND C THEN Z \\
\hline R-4 & IF Z THEN Y \\
\hline
\end{tabular}

Pada tabel 3 di atas terdapat 4 aturan yang tersimpan di dalam knowledge base. Fakta awal yang diberikan hanya : E (artinya : E bernilai benar). Fakta awal yang akan dibuktikan apakah Y bernilai benar (hipotesa : Y)?

Dari hasil eksekusi inferensi backward chaining dapat digambarkan dengan pola pemodelan yang dinyatakan oleh Gambar 16.

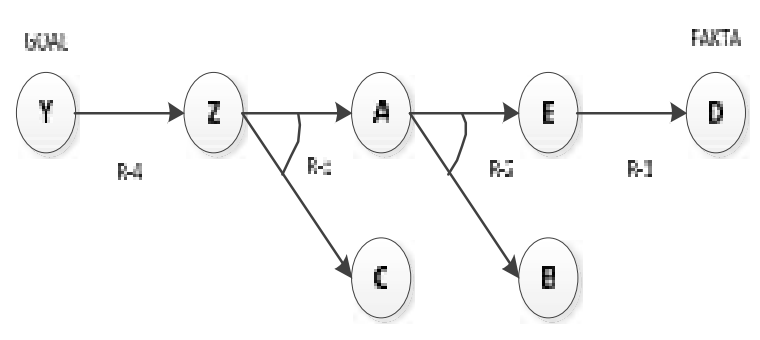

\section{Gambar 16 Alur Inferensi Backward Chaining}

\section{Rancangan Pencarian (Searching)}

Rancangan Pencarian ini digunakan untuk mengakses informasi yang telah disediakan pada Batam Directory. Berikut ini rancangan pencarian yang diinginkan pada gambar 17

Pada form Pencarian ini terdapat beberapa bagian yang masing - masing mempunyai fungsi sebagai berikut :

1. Searching Box berfungsi untuk tempat penulisan kata kunci (key word) yang

2. digunakan untuk mencari (searching) informasi yang diinginkan.

3. Objek Command Buttom SearchBox digunakan sebagai tombol untuk memulai pencarian sesuai dengan Key-word yang telah ditentukan pada Searching Box. 


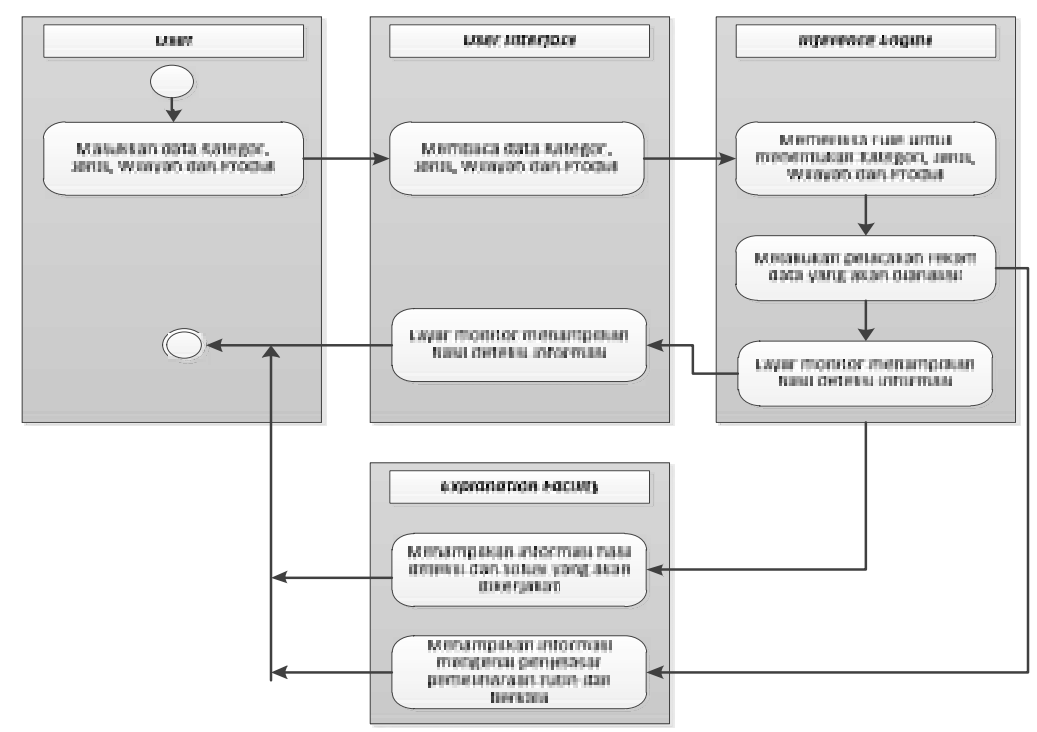

Gambar 19 Rancangan Aktivitas Deteksi Informasi Batam Directory

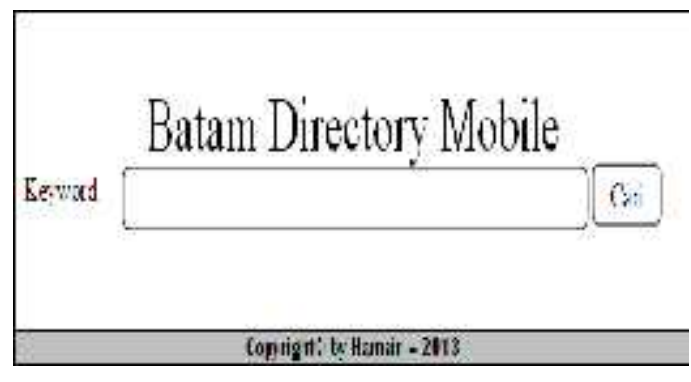

Gambar 17Form Pencarian (Searhing)

\section{Rancangan Form Solusi}

Rancangan form Solusi adalah pada gambar 18 :

Pada form Solusi ini terdapat beberapa bagian yang masing - masing mempunyai fungsi sebagai berikut :

1. Searching Box yang terletak di bawah sub - menu Kategori berfungsi untuk tempat penulisan kata kunci (keyword) yang digunakan untuk mencari (searching) informasi yang diinginkan.

2. Objek Command Buttom Search digunakan sebagai tombol untuk memulai pencarian sesuai dengan Key-word yang telah ditentukan pada Searching Box.

Area Searching Result digunakan untuk menampilkan hasil pencarian. Penyajian hasil pencarian dilakukan dengan masing - masing hasil pencarian dibuatkan link untuk menampilkan informasi secara lengkap.

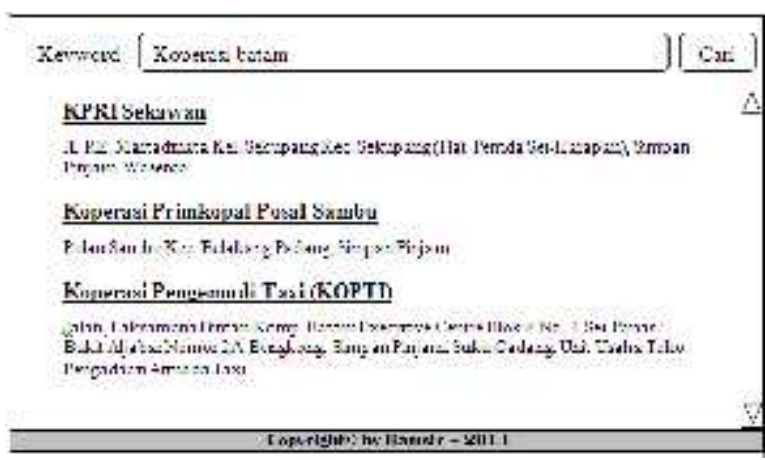

\section{Gambar 18 FormSearching Result}

\section{Explanation Facility}

Explanation Facility (Fasilitas Penjelasan) adalah komponen yang memberikan wawasan untuk proses penalaran. Komponen Penjelasan dapat melacak mana aturan yang digunakan untuk memperoleh hasilnya.Explanation Facility adalah fasilitas yang berisi tentang pemeliharaan dan perawatan sistem informasi dan database Batam Directory secara rutin, berikut dapat dijelaskan sbb : 


\section{Pemeliharaan dan Perawatan Rutin}

Informasi yang disajikan oleh program aplikasi batam directory sangat dibutuhkan oleh penduduk kota batam maupun wisatawan lokal dan mancanegara, serta calon investor yang berminat ber-investasi di kota batam khususnya dan propinsi kepulauan riau pada umumnya.

Sistem informasi batam directory berbasis mobile ini adalah sebuah benda bersifat abstrak yang memerlukan pemeliharaan dan perawatan rutin untuk menjaga sistem kerja tetap stabil. Sama seperti benda lainnya, sistem informasi Batam Directory ini dapat rusak atau tidak bekerja seperti yang seharusnya dilakukan karena mendapat pengaruh atau serangan dari benda lainnya, seperti Virus, Worm, Spyware, Trojan Horse. Selain itu, juga perlu dilakukan perawatan rutin terhadap database yang memiliki pertumbuhan data yang besar agar akses ke database dapat lebih cepat, tidak lelet. Selain itu, agar data selalu up to date, maka harus dilakukan update data secara berkala.

\section{Rancangan Aktivitas Sistem}

Diagram aktivitas menggambarkan berbagai alur aktivitas secara umum dalam sistem yang sedang dirancang, bagaimana masing - masing alur dimulai, decisionapa yang mungkin terjadi dan bagaimana semua alur berakhir. Gambar 19menggambaran aktivitas sistem dari awal pemasukan data (input) hingga hasil akhir(output) yang dihasilkan.

\section{Kesimpulan}

1. Informasi merupakan kebutuhan penting bagi setiap orang dapat lebih mudah melakukan aktifitasnya, terlebih lagi para investor yang diharapkan dapat meningkatkan pertumbuhan ekonomi kota Batam.
2. Penggunaan metode runut mundur (backward chaining) sudah tepat pada penelitian ini, karena terlebih dahulu menentukan tujuan (goal), kemudian bergerak mundur untuk dapat menarik kesimpulan.

3. Hasil (output) dari sistem yang telah dirancang ini dalam bentuk informasi produk atau layanan dari sebuah badan usaha atau kantor layanan pemerintah yang sangat dibutuhkan oleh masyarakat pengguna

\section{Saran}

Sistem informasi Batam Directory berbasis mobile ini bagi penulis belum sempurna dan bermanfaat maksimal karena belum ter-link dengan Google Map atau program sejenisnya yang berfungsi memberikan petunjuk jalan ke tempat perusahaan atau kantor layanan pemerintah yang ingin didatangi. Untuk itu, penulis berharap ada pihak atau peneliti lain yang berkenan mendukung, mengembangkan dan melanjutkan penelitian ini.

\section{DAFTAR PUSTAKA}

Sri Kusumadewi, 2003, Artificial Intellegence (Teknik dan Aplikasinya), Yogyakarta : Graha Ilmu

Peter V. Homeier and Thach C. Le., 2012, Journal ECLIPS : An Extended CLIPS For Backward Chaining and Goal-Directed Reasoning., Information Technology Department, The Aerospace Corporation

Najib Saylani, 2012, Journal Application of Backward Chaining Method to Computer Forensic.,Hofstra University, Hempstead New York 
Meliana Anandari, 2012, Sistem Pakar Untuk Mendiagnosa Gangguan Sistem Pencernaan Pada Manusia Dengan Metode Backward Chaining, AMIKOM Yogyakarta

Hersatoto Lestiyono, 2008, Jurnal Merancang dan Membuat Sistem Pakar., Fakultas Teknologi Informasi, Universitas Stikubank Semarang
Komentar:

Artikel ini diambil dari Tesis MKOM UPI-YPTK yang saya bimbing. Disarankan untuk melibatkan nama pembimbing jika penulis utama (Hamsir) berkenan. 
ISSN :2085-6989 